\title{
Design and Simulation of Photo-voltaic Water Pumping System for Irrigation
}

\author{
Abdulbasit Nasir \\ Department of Mechanical Engineering, Hawassa University, Hawassa, Ethiopia
}

Email address:

abdulbasitn1@gmail.com

\section{To cite this article:}

Abdulbasit Nasir. Design and Simulation of Photo-voltaic Water Pumping System for Irrigation. Advances in Applied Sciences. Vol. 4, No. 2, 2019, pp. 51-63. doi: 10.11648/j.aas.20190402.14

Received: March 19, 2019; Accepted: May 14, 2019; Published: June 12, 2019

\begin{abstract}
In locations where electricity is not available, other means are necessary to pump water for different applications. Using a diesel pump to deliver water causes economic and environmental problems. The higher price of diesel increases operation costs of diesel water pumping system thereby reducing the incomes. In addition, the use of a diesel pump emits a considerable amount of $\mathrm{CO}_{2}$ which cause global warming. A possible solution to these problems is using renewable energy source like solar power, which is environmentally friend and available for free. This paper presents the design and simulation of a photovoltaic water pumping system for irrigation of a potato farm located at a place named Gerenbo in south-west Ethiopia. The system was designed by considering the site's topography and local meteorological data. The PV system designing was made in such a way that, capable of irrigating a hectare area potato farm with daily water requirement of $7 \mathrm{~m}^{3}$ and total dynamic head of $21 \mathrm{~m}$. To run simulations, different tools have been used. Those include CROPWAT, MatLab, and HOMER. Furthermore, after seizing all components and sub-systems, the entire system (from solar radiation to water production) was simulated by using PVsyst. The economic and environmental aspects of PV water pumping systems have been studied. Based on the projected system lifetime production, the equivalent cost of water for PVWPs and DWPs is $\$ 0.1187 / \mathrm{m}^{3}$ and $\$ 0.3526 / \mathrm{m}^{3}$ respectively. Replacement of diesel-powered water pumping system results in an annual reduction of $\mathrm{CO}_{2}$ emissions by $1500 \mathrm{~kg}$.
\end{abstract}

Keywords: Photo-voltaic, Water Pumping System, System Simulation, Diesel Engine, Irrigation, Economic Analysis, Reduction in $\mathrm{CO}_{2}$ Emission

\section{Introduction}

When considering the development of the country, energy is one of the key points. Energy can be generated from renewable and non-renewable energy sources. High prices, fast depletion rate and environmental impacts of fossil fuels create problems in electricity generation through conventional energy sources. PV water pumping system have emerged as a promising alternative to conventional diesel and electricity powered irrigation pumps [1].

Solar photovoltaic water pumping has been recognized as suitable for grid-isolated rural locations in developing countries like Ethiopia where there are high levels of solar radiation. The recognizable challenge is the high initial cost of solar water pumping systems; while it demands virtually no maintenance, and requires no fuel [2].
Solar water pumps are most often applied when utility power is not readily available. In Ethiopia, about $73.44 \%$ of the population lives without access to electricity [World Bank 2015].

PV power is a more reliable energy source for almost all parts of Ethiopia. This is due to the fact that Ethiopia is situated near the equator and hence solar insolation potential is sufficiently available here. [3-5].

The agricultural sector is the leading sector in the Ethiopian economy, comprising $47.7 \%$ of the total GDP, as compared to $13.3 \%$ from industry and $39 \%$ from services [6]. Most of the time, Ethiopian farmers use a diesel-driven generator for irrigation. But diesel pumps have many drawbacks such as high running and maintenance cost, unreliable supply of fuel, and poor availability of spare parts. The site selected for this research is directly facing these problems. Finding the best solution to the problem is very important to increase the 
profitability of farmers. Using renewable energy is a feasible option to fulfill the energy need without affecting the environment. The objective of this work is to design an efficient and cost-effective photovoltaic water pumping system for irrigation of a potato farm, considering the specific area of Gerenbo to solve drawbacks of a diesel water pump and increase the profitability of the farmers.

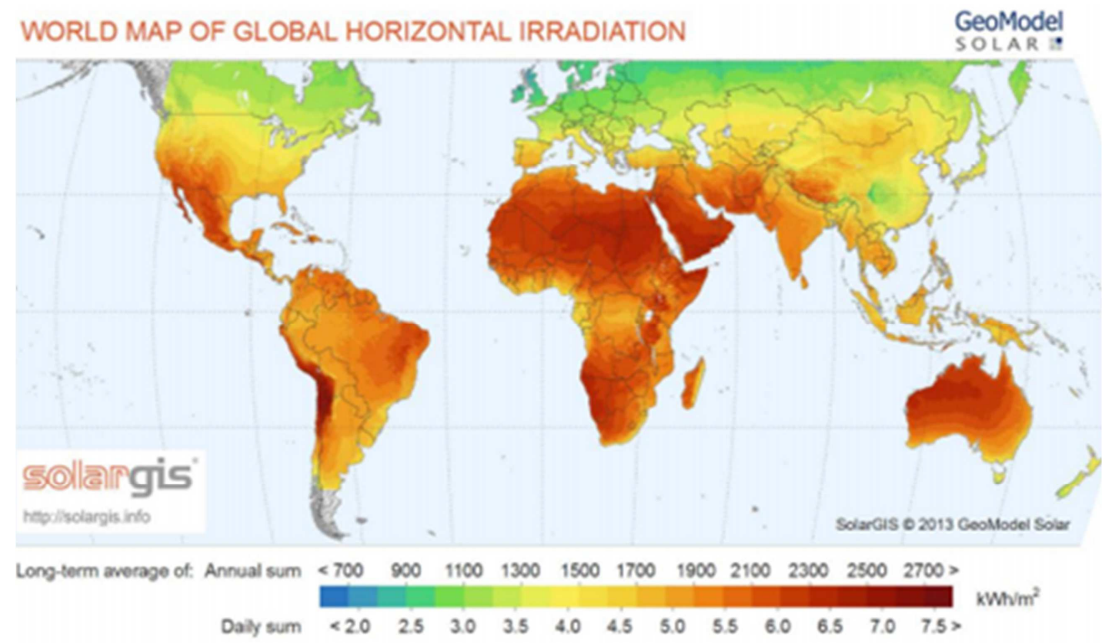

Figure 1. World map of global horizontal irradiation.

EUROPA $>E C>J R C>I E>R E>S O L A R E C>P V G I S>I$ Interactive maps $>$ africa

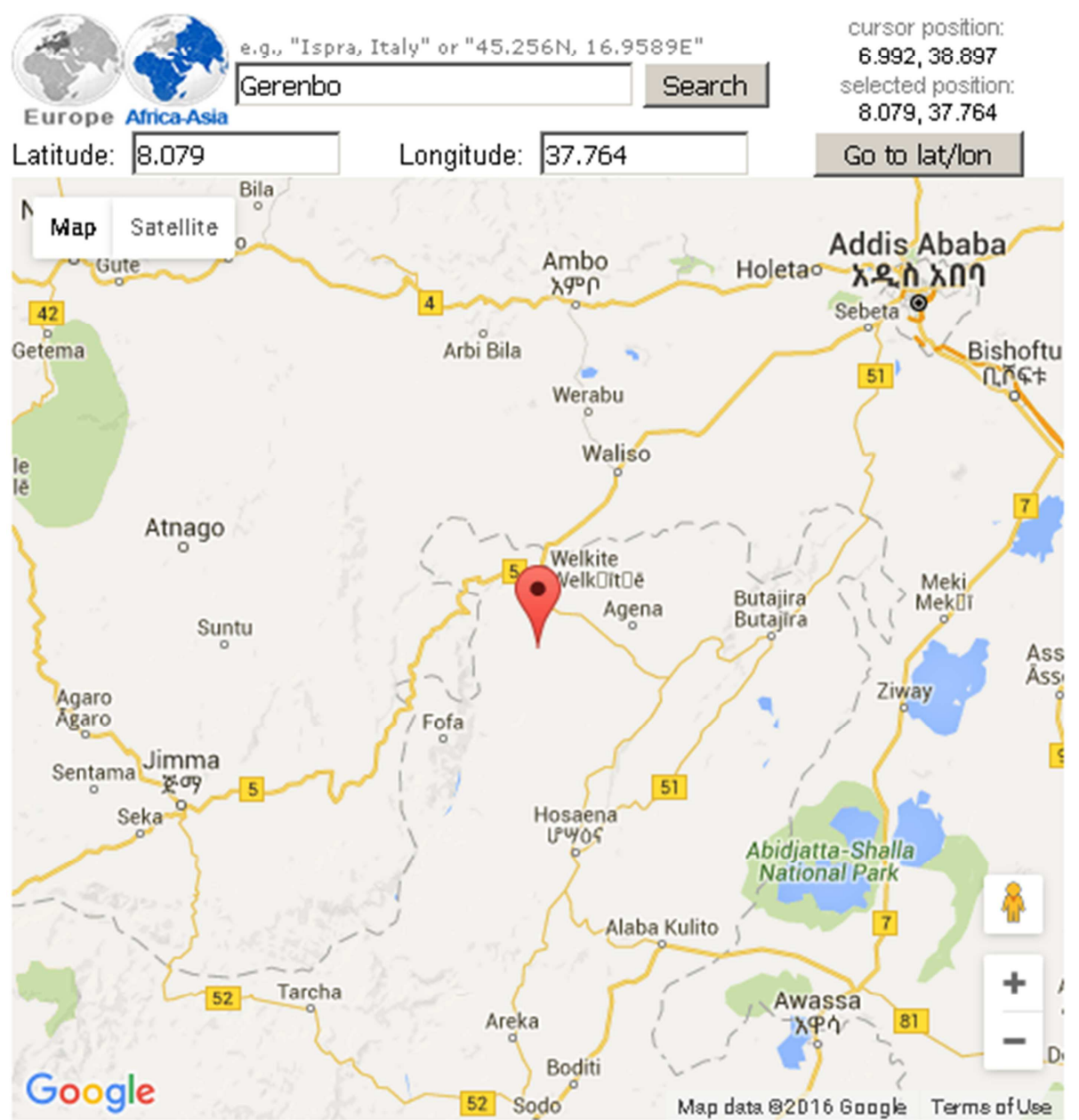

Figure 2. Site location. 
The site selected for this research is Gerenbo, which is found in Gurage Zone located $30 \mathrm{~km}$ from Welkite and $150 \mathrm{~km}$ from the capital city of the country in the southwest direction (Figure 2). Gerenbo is geographically situated at $8^{\circ} 17^{\prime} \mathrm{N} \quad 37^{\circ} 47^{\prime} \mathrm{E}$ with an elevation of 1930 meters above mean sea level. Winque is a tributary of the Gibe River. It flows year-round with sufficient capacity. Haram, Gotam, and Wabe are major Feeders. Other minor tributaries also contribute a considerable volume of water.

\section{Determination of Design Data}

\subsection{Crop Water Requirement}

The first step in designing a solar-powered water pump system is to determine the overall water requirement for the purpose. The water requirement of crops varies with the type of crop, time and depends on the season and growth of crops [7-9]. The type of soil and the climatic parameters are also other factors that affect system design. In this specific research, the crop is potato and the type of soil is categorized under load.

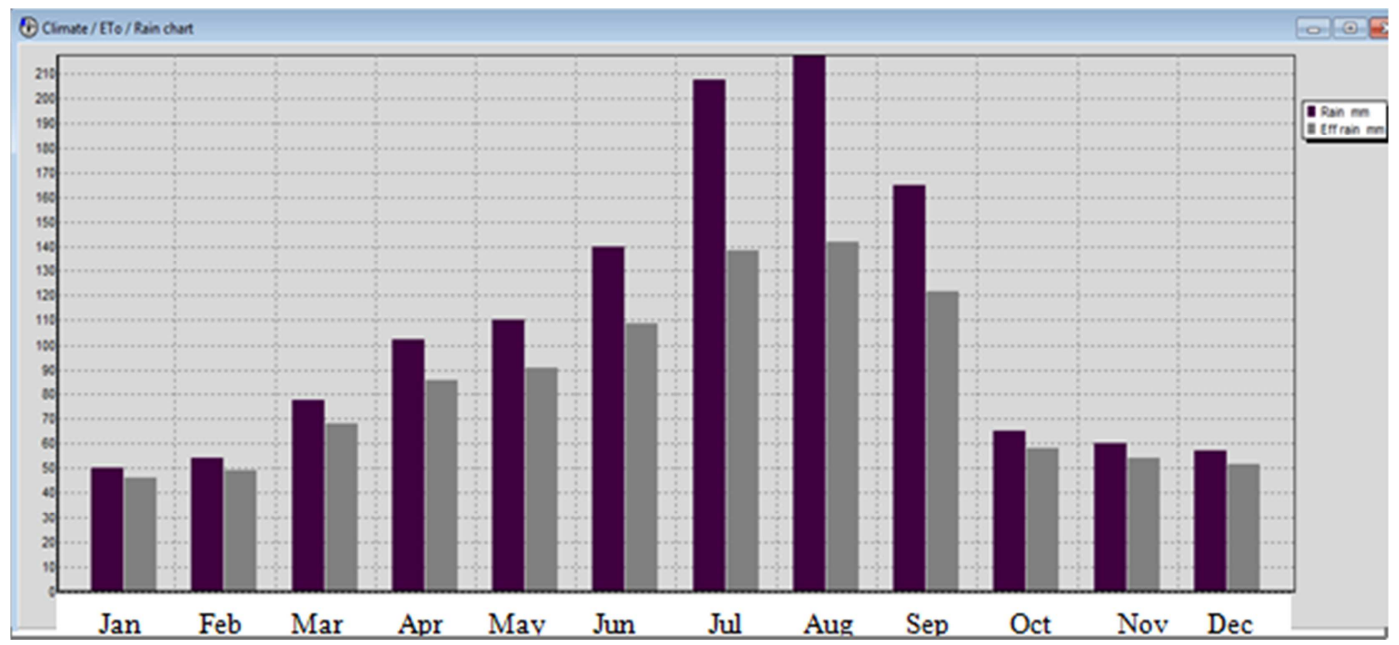

Figure 3. Month-wise average rainfall data of the site.

Irrigation is the artificial application of water to land for substitute rainfall water. Regional metrological data shows that the amount of rainfall is decreased radically from October (figure 3), therefore, October first is taken as the starting date of irrigation.

\subsection{Estimation of Solar Radiation}

\subsubsection{Estimation of Clear-Sky Radiation on Horizontal Surface}

Hottel and Whiller presented a simple model for the estimation of beam radiation in clear sky conditions [10]. The required input data are; the altitude of the location $\mathrm{A}$, day number of the year $N$ and the zenith angle $(\theta z)$. The clear sky beam radiation on a horizontal surface is:

$$
\mathrm{I}_{\mathrm{b}=} \mathrm{I}_{\mathrm{n}} \tau_{\mathrm{b}} \cos \theta_{\mathrm{z}}
$$

Where:

$$
\begin{gathered}
I_{n}=I_{s c}\left[1.0+0.033 \cos \left(\frac{360 N}{365}\right)\right) \\
\tau_{b}=a_{0}+a_{1} e^{\left(-k / \cos \theta_{z}\right)}
\end{gathered}
$$

Where,

$$
\begin{gathered}
\mathrm{a}_{\mathrm{o}}=\mathrm{a}_{\mathrm{o}}^{*} \mathrm{r}_{\mathrm{o}}, \mathrm{a}_{1}=\mathrm{a}_{1}^{*} \mathrm{r}_{1}, \mathrm{k}=\mathrm{k}^{*} \mathrm{r}_{\mathrm{k}} \\
\mathrm{a}_{\mathrm{o}}^{*}=0.4237-0.00821(6-\mathrm{A})^{2} \\
\mathrm{~A}_{1}^{*}=0.5055+0.00595(6.5-\mathrm{A})^{2}
\end{gathered}
$$

$$
\begin{gathered}
\mathrm{k}^{*}=0.2711+0.01858(2.5-\mathrm{A})^{2} \\
\mathrm{r}_{\mathrm{o}}=0.95, \mathrm{r}_{1}=0.91, \mathrm{r}_{\mathrm{k}}=1.02
\end{gathered}
$$

The clear sky diffuse radiation is:

$$
\mathrm{I}_{\mathrm{d}}=\mathrm{I}_{\mathrm{n}} \tau_{\mathrm{d}} \cos \theta_{\mathrm{z}}
$$

The total clear sky radiation on a horizontal surface could be estimated as:

$$
\mathrm{I}_{\mathrm{T}}=\mathrm{I}_{\mathrm{b}}+\mathrm{I}_{\mathrm{d}}
$$

\subsubsection{Estimation of Solar Radiation on Inclined Surface}

The following formula was given by Liu and Jordan [10], for evaluating the total radiation on a surface of arbitrary orientation from the knowledge of beam and diffuses radiation on the horizontal surface.

$$
\mathrm{I}_{\mathrm{T}}=\mathrm{I}_{\mathrm{b}} \mathrm{R}_{\mathrm{b}}+\mathrm{I}_{\mathrm{d}} \mathrm{R}_{\mathrm{d}}+\mathrm{rR}_{\mathrm{r}}\left(\mathrm{I}_{\mathrm{b}}+\mathrm{I}_{\mathrm{d}}\right)
$$

Where: $r=$ reflectivity of the ground $=0.2$. $R b, R d$, and $\mathrm{Rr}$ are known as conversion factors for the beam, diffuse and reflected components respectively.

The expressions for these are as follows:

$$
\mathrm{R}_{\mathrm{b}}=\frac{\cos \theta}{\cos \theta_{\mathrm{z}}}, \mathrm{R}_{\mathrm{d}}=\frac{1+\cos \beta}{2}, \mathrm{R}_{\mathrm{r}}=\left(\frac{1-\cos \beta}{2}\right)
$$

Sizing of a photovoltaic system is based on the worst operating condition. For December the ratio of water requirement to solar radiations was largest and the 
recommended average date of the month is the $10^{\text {th }}$ day.

Therefore, December 10 i. e. $\mathrm{N}=344$ is chosen for PV sizing. The declination angle can be calculated using

$$
\delta=23.45 \sin \left[\frac{360}{365}(284+\mathrm{N})\right]
$$

Hour angle $\omega$ and solar time ST in an hour are related as:

$$
\omega=(\mathrm{ST}-12) \times 15^{0}
$$

For the horizontal surface, zenith $(\theta z)$ can be calculated using:

$$
\cos \theta \mathrm{z}=\cos \phi \times \cos \delta \times \cos \omega+\sin \delta \times \sin \phi
$$

\section{Designing and Sizing of PVWPs}

\subsection{Water Storage Design}

Size of the water storage tank which depends on water to be pumped per day and daily water consumption [11]. The capacity of the water storage should be sufficient for two up to ten days' worth of water storage in the event of extended cloudy weather or maintenance issues.

Elevated plastic tankers have many drawbacks; in addition to their higher cost, they also increase system head loss, in order to solve these problem design appropriate earthen farm pond for storing water as shown in (figure 4). The storage should be provided with a lining, to minimize water wastage.

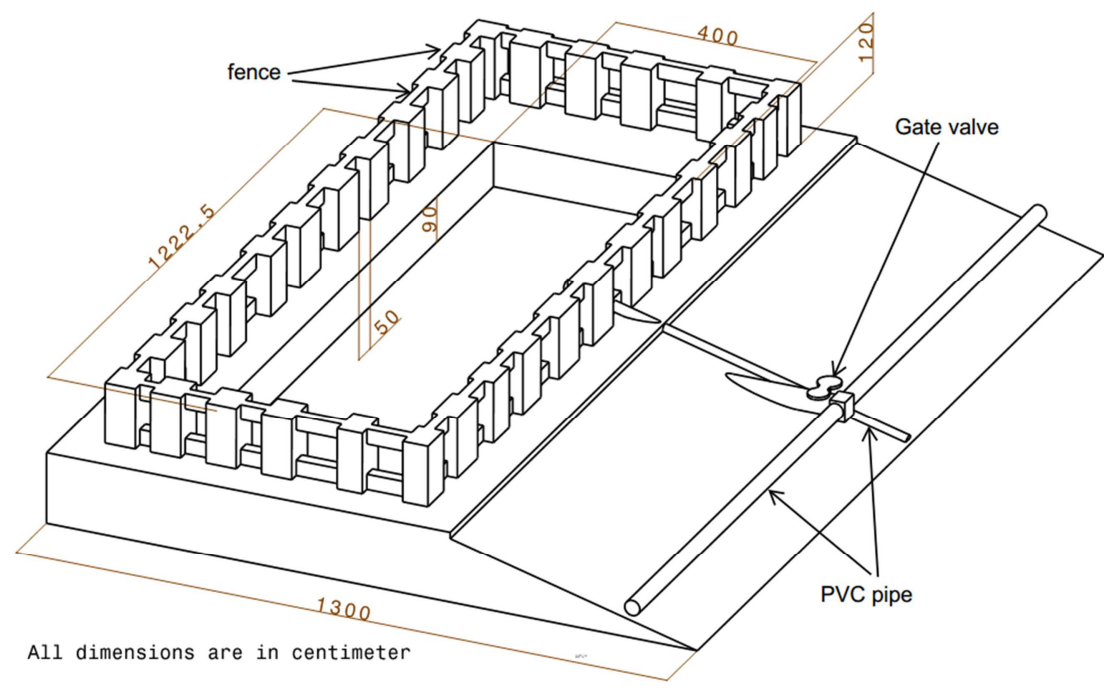

Figure 4. Designed water storage.

\subsection{System Layout Design}

Design layout of the system will be identifying all necessary distances and elevations.

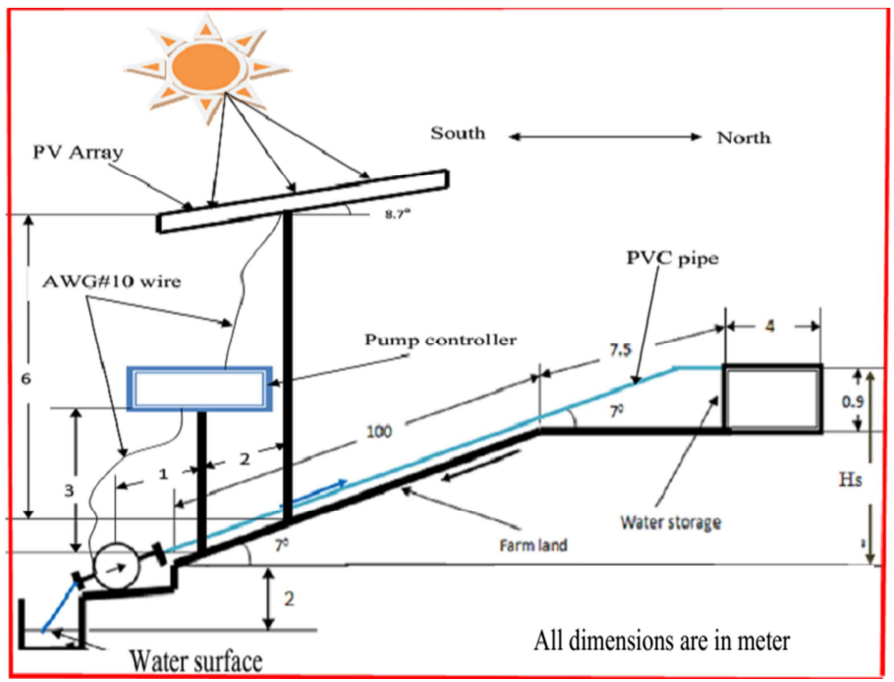

Figure 5. System layout (Side view).

\subsubsection{Performance Characteristics of the Piping System}

A system head curve indicates the relationship between flow and hydraulic losses in a given piping system. Since hydraulic losses are functions of the rate of flow, size, and length of pipe, and size, number, and type of fittings. 


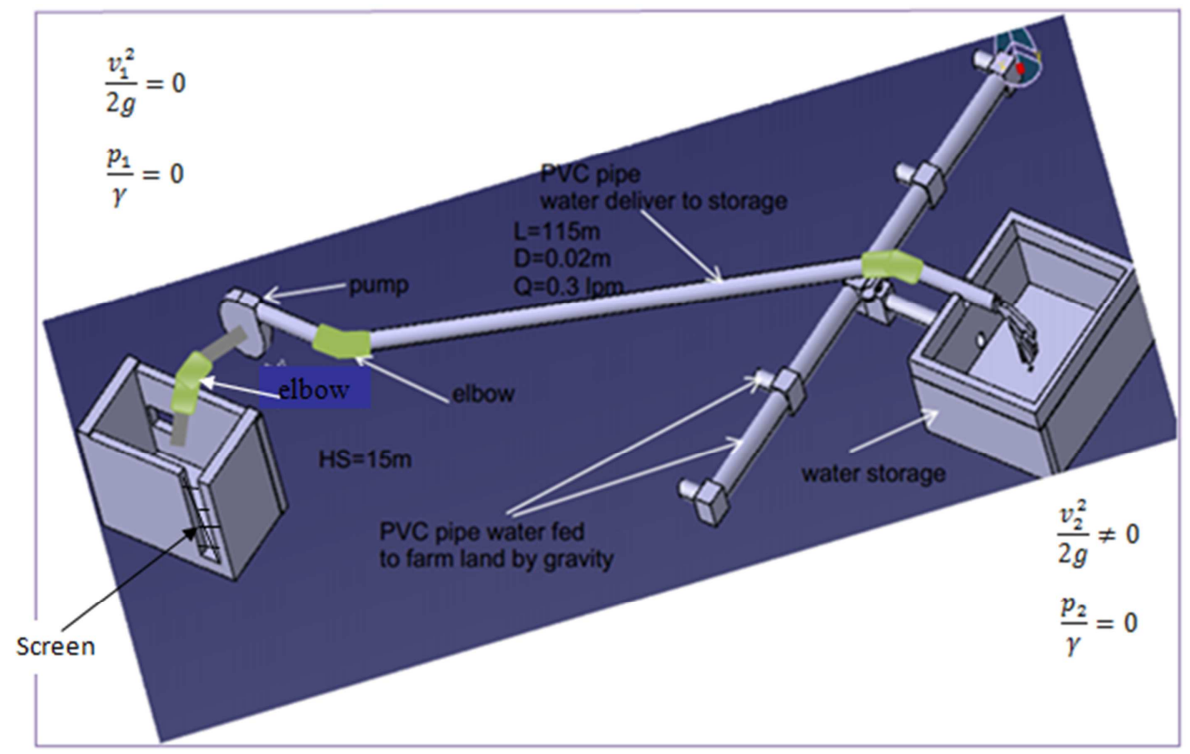

Figure 6. System piping network.

The general equation to calculate system head loss due to friction is:

$$
h_{f}=h_{\text {pipe }}+3 * h_{\text {elbow }}+h_{f v}+h_{c v}+h_{\text {screen }}+\text { velocity losses }
$$

Average velocity,

$$
V=\frac{Q}{A}
$$

For PVC, $\varepsilon \approx 1.5(10)^{-6} \mathrm{~m}$, relative roughness is: $\frac{\varepsilon}{D}=r$ and Reynolds number

$$
R_{e}=\frac{V D}{v}
$$

Where, $\mathrm{V}=$ average fluid velocity

$\mathrm{D}=$ pipe diameter

$v=$ viscosity of water at $10^{\circ} \mathrm{C}$

\subsubsection{Frictional Head Loss}

The Darcy Equation is a theoretical equation that predicts the frictional energy loss in a pipe based on the velocity of the fluid and the resistance due to friction. Normally, it is used to calculate head loss due to friction in a turbulent flow.

$$
h_{\text {pipe }}=f \frac{L}{D} \frac{V^{2}}{2 g}
$$

Equation 13 is called the Darcy-Weisbach equation.

The Darcy friction factor in turbulent flow is determined from the Moody diagram or by solving it from the Blasius, Swami-Jain or Haaland equations.

The Blasius equation is valid up to Reynolds number $10^{5}$.

$$
f=\frac{0.316}{R_{e}{ }^{0.25}}
$$

Where: -f Darcy friction factor.

$\mathrm{R}_{\mathrm{e}}$ the Reynolds number.

Swamee and Jain have developed the following equation.

$$
f=0.25\left[\log \left(\frac{r}{3.7}+\frac{5.74}{R_{e} 0.9}\right)\right]^{-2}
$$

In which, $\mathrm{r}$ is relative roughness.

Haaland has deduced the equation.

$$
\frac{1}{\sqrt{f}}=-1.8 \log \left[\left(\frac{r}{3.7}\right)^{1.11}+\frac{6.9}{R_{e}}\right]
$$

From the Moody diagram, $\mathrm{f}=0.03$.

Taking the Darcy friction factor $\mathrm{f}=0.03$ to calculating system head loss.

Loss coefficient for pipe components $\left(h_{L}=K_{L} \frac{V^{2}}{2 g}\right)$.

There are three elbows in the system (figure 6).

$$
h_{\text {elbow }}=3 K_{L} \frac{V^{2}}{2 g}
$$

The foot valve is required because the pump is located higher than the water level.

$$
h_{f v}=K_{L} \frac{V^{2}}{2 g}
$$

Check Valve allows the pump to start easier. It also prevents backflow when changing filter cartridges.

$$
\begin{gathered}
h_{c v}=K_{L} \frac{V^{2}}{2 g} \\
\text { Velocity loss }=\frac{V^{2}}{2 g}
\end{gathered}
$$

\subsection{Pump Selection}

Selection of the pump depends upon the following factors [12]. The requirement of the water, the requirement of total vertical head, length of the pipe, the temperature of the water, and quality of the water.

Based on design data, the pump chosen here is SCB 10$150-120 \mathrm{BL}$ surface solar pump. It is a pressure booster type 
centrifugal pump equipped with a DC brushless motor and designed for use in standalone water delivery systems, specifically for water delivery in remote locations. Flow rates up to (42LPM) with a total dynamic head of $28.9 \mathrm{~m}$. The rated maximum power consumption is $236 \mathrm{~W}$. It operates with voltage (75 V DC).

\subsubsection{Performance Characteristics of SCB 10-150-120BL Pump}

A plot of head and flow rate at a given speed forms the fundamental performance characteristics of a pump. It is useful to plot also the efficiency $\eta$ against flowrate $Q$.

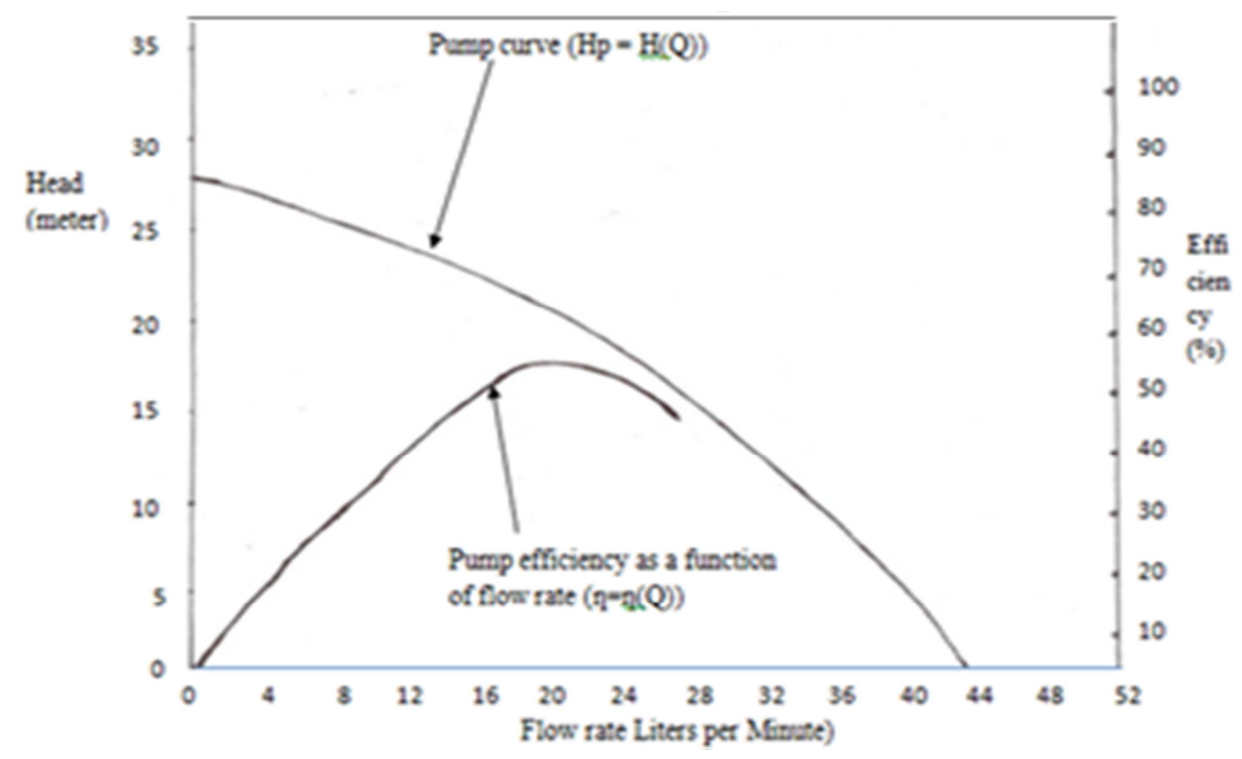

Figure 7. Performance characteristics curve of the selected pump [13].

\subsubsection{System Configuration}

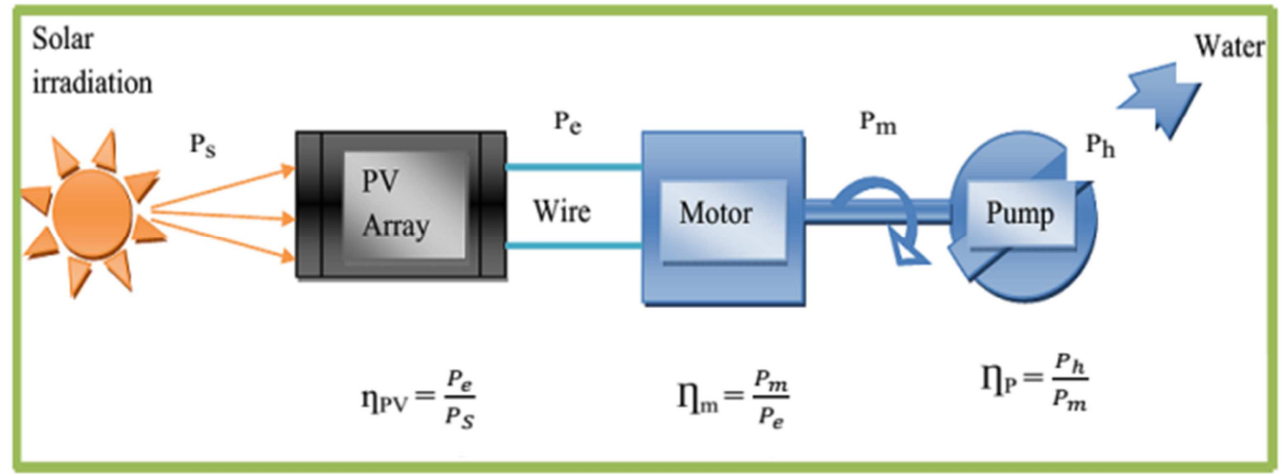

Figure 8. Schematic diagram of the system configuration.

In figure 8;

$$
\begin{gathered}
P_{h}=\text { Hydraulic power } \\
P_{m}=\text { Mechanical power } \\
P_{e}=\text { Electrical power } \\
?_{p}=\text { pump efficiency } \\
?_{m}=\text { motor efficiency }
\end{gathered}
$$

And $P_{h}=\rho g Q_{w} H_{w}, P_{M}=\frac{P_{h}}{{ }_{p w}}, P_{e}=\frac{P_{m}}{{ }^{\square_{m w}}}$

Where,

$$
\rho=\text { density of water }=1000 \frac{\mathrm{kg}}{\mathrm{m}^{3}}
$$

$$
g=\text { gravity of earth }=9.81 \frac{\mathrm{m}}{\mathrm{s}^{2}}
$$

Sizing of PV array is done based on the electrical power requirement of the system.

\subsection{Sizing and Selection of PV Module}

\subsubsection{Module Selection}

The selected panel should provide the minimum energy required to run the pump. However, the panels must also have an additional capacity of $25 \%$ to account for any potential reduction in power [14].

BP Solar BP 7180 S Saturn technology module, is selected for this purpose because of its best efficiency and better temperature coefficient. 


\subsubsection{Characteristics of Selected Module}

Electrical and mechanical features of BP $7180 \mathrm{~S}$ is shown in table 1. Power-Voltage characteristic of the selected module is illustrated in (figure 9).

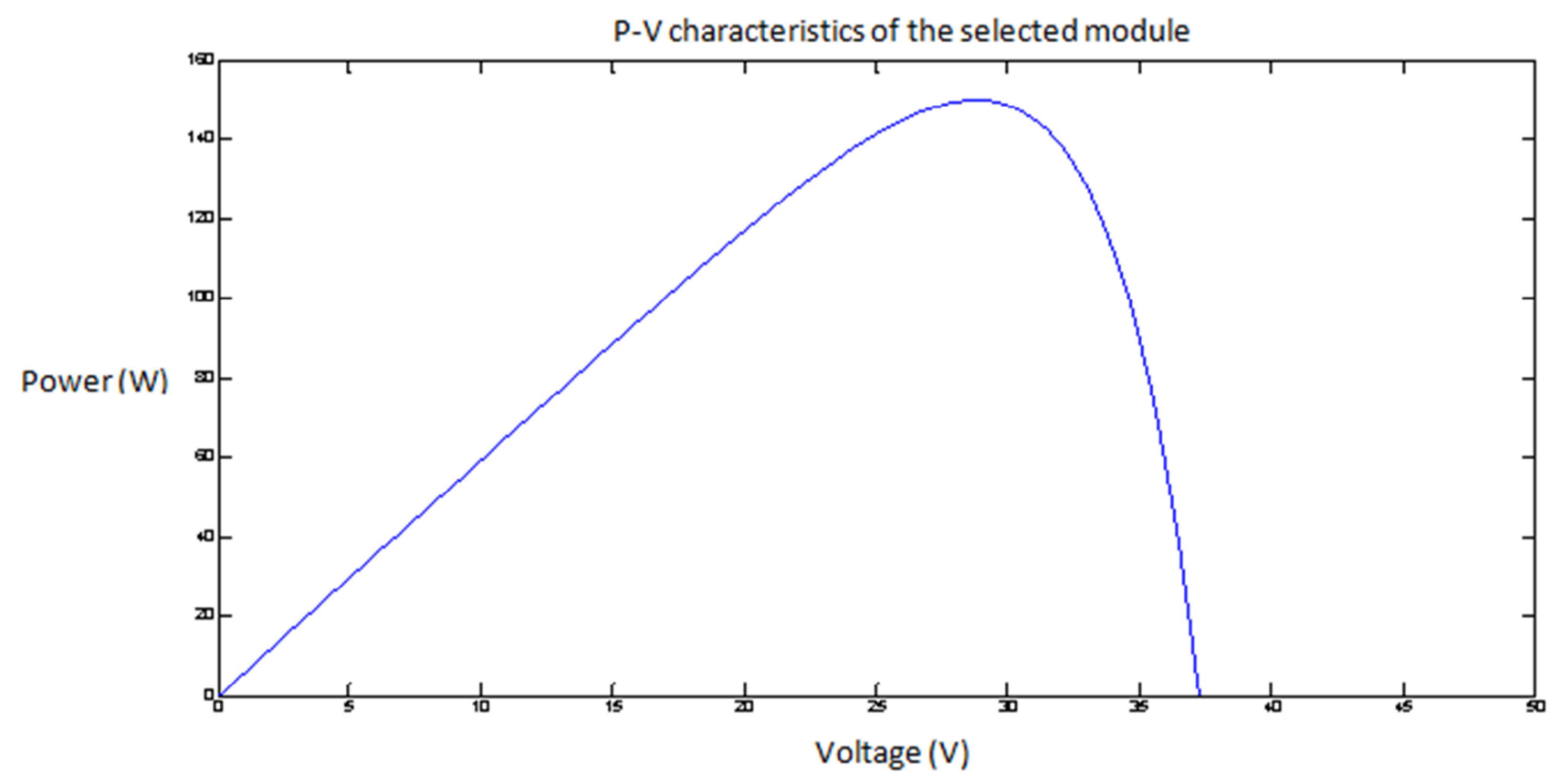

Figure 9. Power-Voltage characteristics of the selected module.

Table 1. Electrical and mechanical characteristics of the selected module [15].

\begin{tabular}{ll}
\hline Electrical characteristics & BP 7180 S \\
\hline Maximum power $\left(\mathrm{P}_{\max }\right)$ & $180 \mathrm{~W}$ \\
Power tolerances & $-3 \% /+5 \%$ \\
Number of cell & 72 \\
Voltage at $\mathrm{P}_{\max }\left(\mathrm{V}_{\mathrm{mp}}\right)$ & $36 \mathrm{~V}$ \\
Current at $\mathrm{P}_{\max }\left(\mathrm{I}_{\mathrm{mp}}\right)$ & $5 \mathrm{~A}$ \\
Open-circuit voltage $\left(\mathrm{V}_{\mathrm{oc}}\right)$ & $44.2 \mathrm{~V}$ \\
Short-circuit current $\left(\mathrm{I}_{\mathrm{sc}}\right)$ & $5.3 \mathrm{~A}$ \\
Temperature coefficient of $\mathrm{I}_{\mathrm{sc}}$ & $0.065 \pm 0.015 \% /{ }^{\circ} \mathrm{C}$ \\
Temperature coefficient of $\mathrm{V}_{\mathrm{oc}}$ & $-160 \pm 20 \mathrm{mV} /{ }^{\circ} \mathrm{C}$ \\
Temperature coefficient of power & $\pm 0.05 \% /{ }^{\circ} \mathrm{C}$ \\
NOCT & $47 \pm 2{ }^{\circ} \mathrm{C}$ \\
Series fuse rating & $15 \mathrm{~A}$ \\
Peak efficiency & $14.3 \%$ \\
Mechanical characteristics & \\
type & Polycrystalline silicon \\
Output terminal type & Multi contact connector type 3 \\
Frame color & Clear \\
length & $1.593 \mathrm{~m}$ \\
width & $0.80 \mathrm{~m}$ \\
depth & $0.05 \mathrm{~m}$ \\
weight & $15.9 \mathrm{~kg}$ \\
Installation method & Rack-mounted \\
\hline
\end{tabular}

$80 \%$ power output warranty period of 25 years.

\section{Economic Analysis of the System}

Every project needs to perform an economic evaluation to make sure that it is feasible or not. In this section, the economic evaluation of PVWP system is compared with diesel water pumping. The comparison is conducted in terms of initial investment costs (IIC), life cycle cost (LCC).

\subsection{Initial Investment Cost (IIC)}

The higher component price made PV water pumping system has a higher initial investment cost than the dieselpowered pump but its recurrent cost proved to decline over their current cost. However, in remote areas aspects such as lower operation \& maintenance costs, the more reliability, as well as the longer expected useful life of PV systems, could economically justify the higher initial cost of PV systems.

\subsection{Life Cycle Cost Analysis (LCCA)}

The life cycle costs analysis has been computed using Homer and MS Excel; it takes into account all costs of acquiring, owning, and disposing expenses incurred over the life period of the systems. The life-cycle cost of both alternatives can be calculated using the formula:

$$
L C C=C C+M C+E C+R C-S C
$$

Where, $\mathrm{CC}=$ Capital cost of a project

$\mathrm{MC}=$ Maintenance cost

$\mathrm{EC}=$ Energy cost

$\mathrm{RC}=$ Replacement cost

$\mathrm{SC}=$ Salvage value 


\section{Result and Discussion}

\subsection{Available Solar Radiation}

Table 2. An estimated hourly solar resource of the site for December 10.

\begin{tabular}{llllll}
\hline Time & Beam $\left(\mathbf{w} / \mathbf{m}^{2}\right)$ & Diffuse $\left(\mathbf{w} / \mathbf{m}^{2}\right)$ & Global $\left(\mathbf{w} / \mathbf{m}^{2}\right)$ & Hour angle $\omega^{(0)}$ & Calculated rad. On the inclined surface $\left(\mathbf{w} / \mathbf{m}^{2}\right)$ at $\boldsymbol{\beta}=\mathbf{8 . 1 7 ^ { 0 }}$ \\
\hline 9 AM & 545.39 & 67.15 & 612.54 & -45 & 657.81 \\
$10 \mathrm{AM}$ & 602.32 & 74.55 & 676.87 & -30 & 725.93 \\
$11 \mathrm{AM}$ & 702.09 & 78.05 & 780.14 & -15 & 836.87 \\
$12 \mathrm{AM}$ & 736.30 & 79.32 & 815.62 & 0 & 874.98 \\
$1: 30$ PM & 725.66 & 77.11 & 802.77 & 22.5 & 861.22 \\
\hline
\end{tabular}

The Estimation of solar resources can be alternatively performed with the software Cropwat. The result indicates that the site is blessed with good solar radiation levels, varying from a daily average of $3.92 \mathrm{kWh} / \mathrm{m}^{2}$ in the least irradiated month (nonirrigating months) to $5.82 \mathrm{kWh} / \mathrm{m}^{2}$ in those months with best solar irradiance.

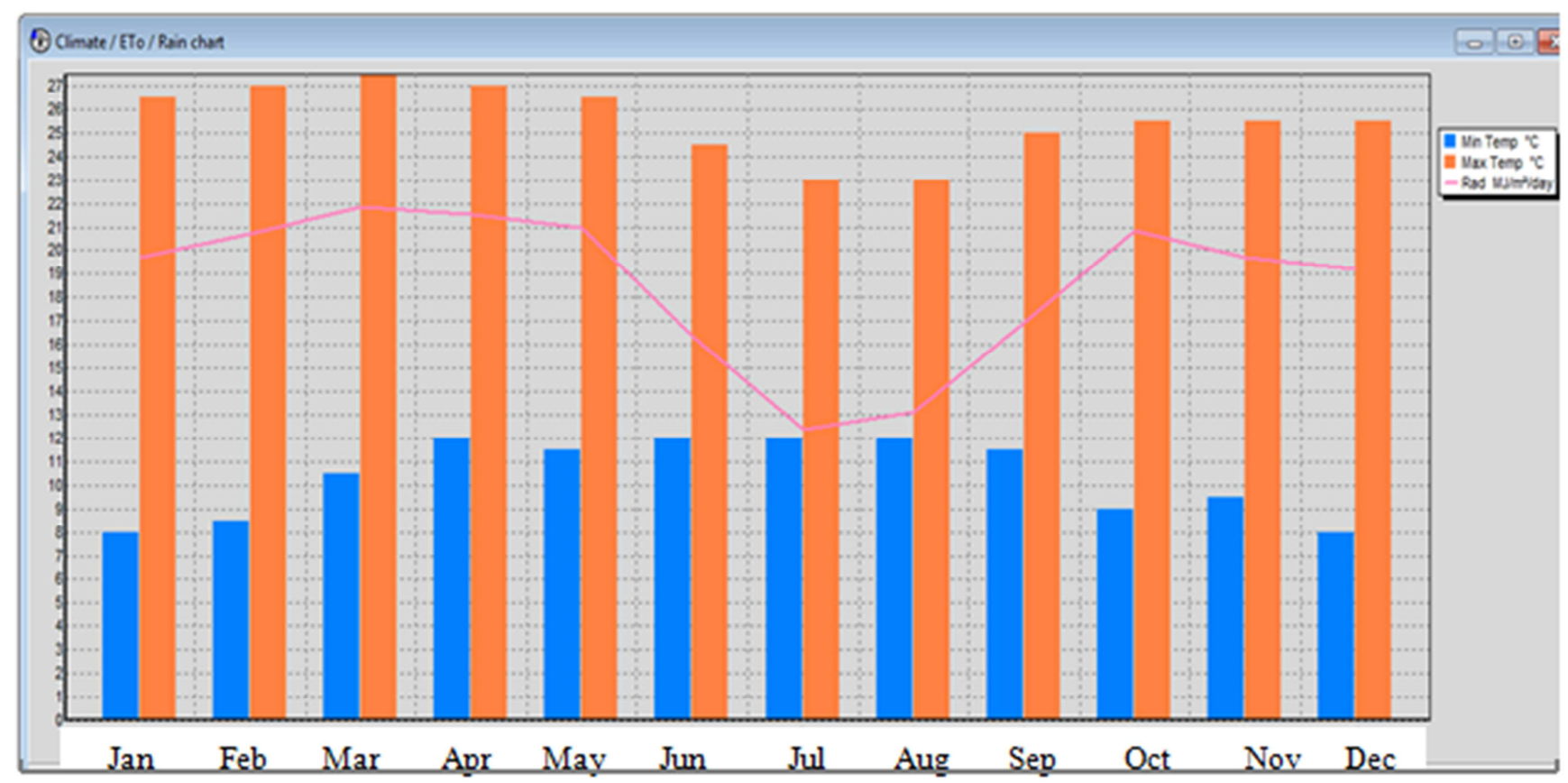

Figure 10. Monthly average simulated solar radiation.

\subsection{Piping System Head Losses}

Table 3. Head losses as a function of $Q$.

\begin{tabular}{llll}
\hline $\mathbf{Q} /(\mathbf{l} / \mathbf{m})$ & Static head $(\mathbf{m})$ & Friction losses $(\mathbf{m})$ & TDH $(\mathbf{m})$ \\
\hline 0 & 15 & 0.15 & 15.15 \\
4 & 15 & 0.21 & 15.21 \\
8 & 15 & 1.18 & 16.18 \\
12 & 15 & 3.35 & 18.35 \\
16 & 15 & 4.00 & 19.00 \\
18 & 15 & 6.00 & 21.00 \\
22 & 15 & 9.00 & 24.00 \\
26 & 15 & 12.00 & 27.00 \\
\hline
\end{tabular}

Performance characteristics of the piping system (Head losses as a function of Q) can be illustrated as follows. 


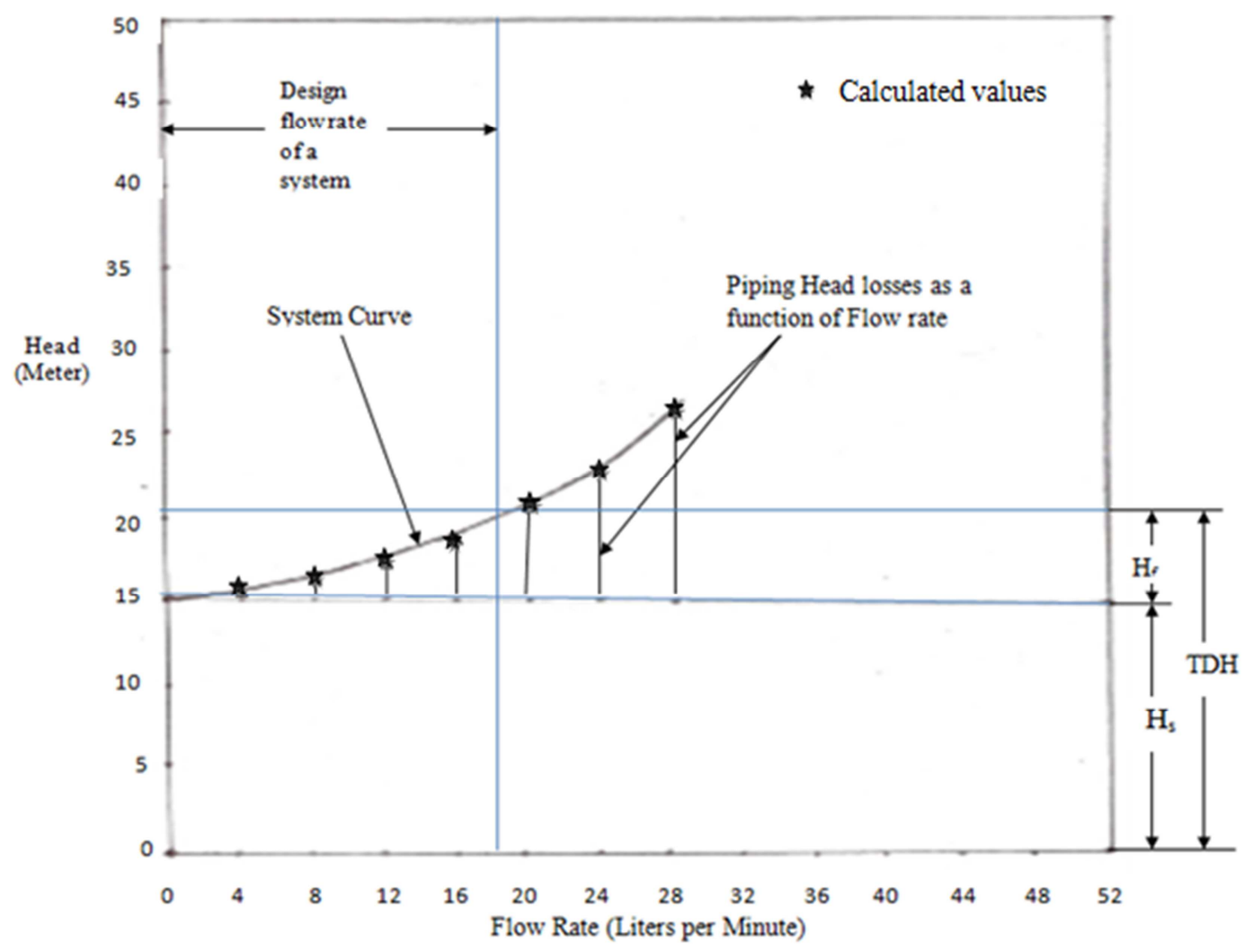

Figure 11. Performance characteristics of the piping system.

\subsection{Working Point}

A working point is the TDH-flow pair corresponding to the pump function, taking into account the head loss in the pipe system. When the pump operates, a particular working point is reached, corresponding to the balance between flow and TDH.

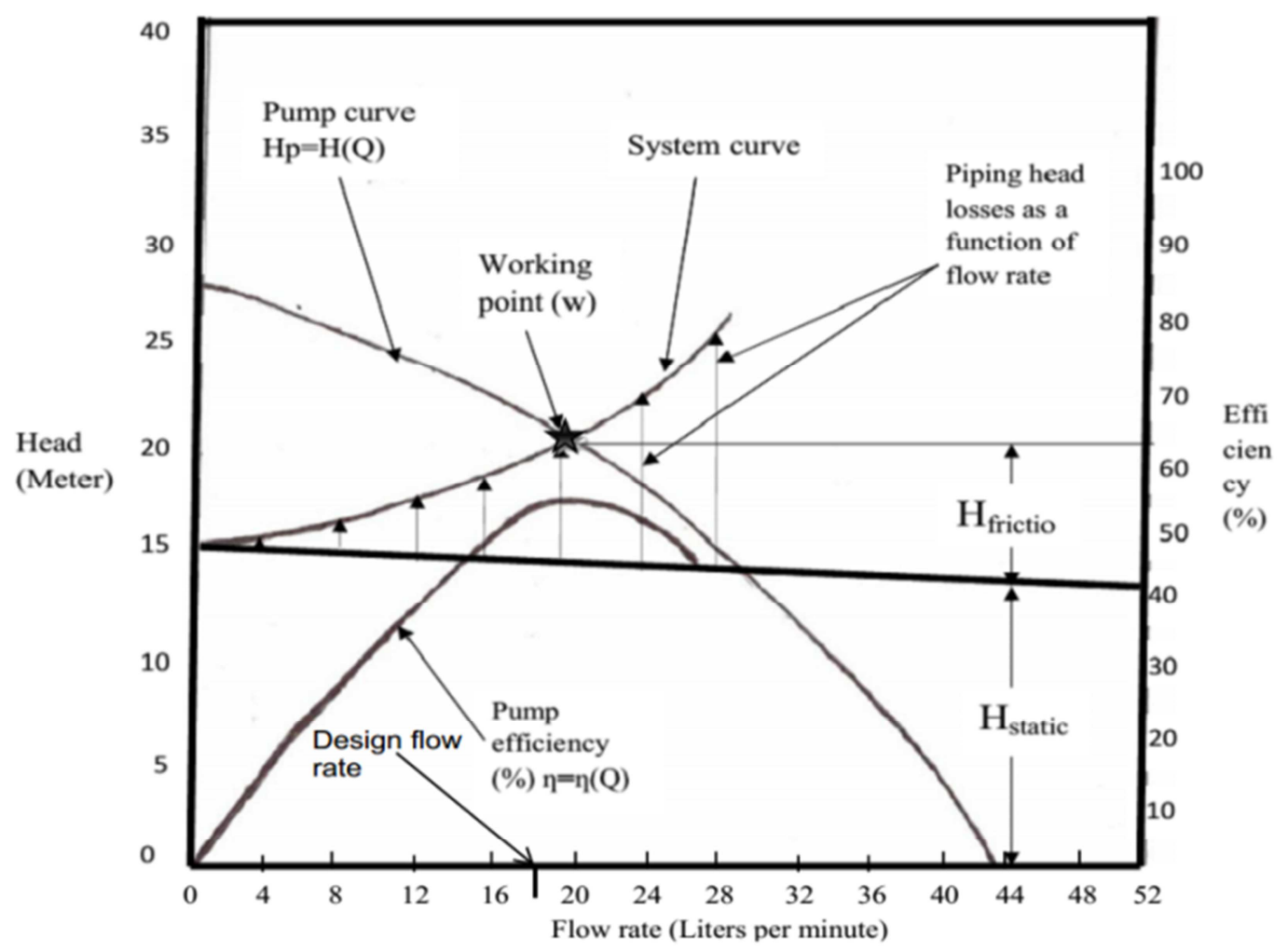

Figure 12. System working point. 
Figure 12 shows, the pump flow rate at the working point is close to the design flow rate. This indicates that the selected pump is working in its best operating condition.

\subsection{The Monthly Average PV Output}

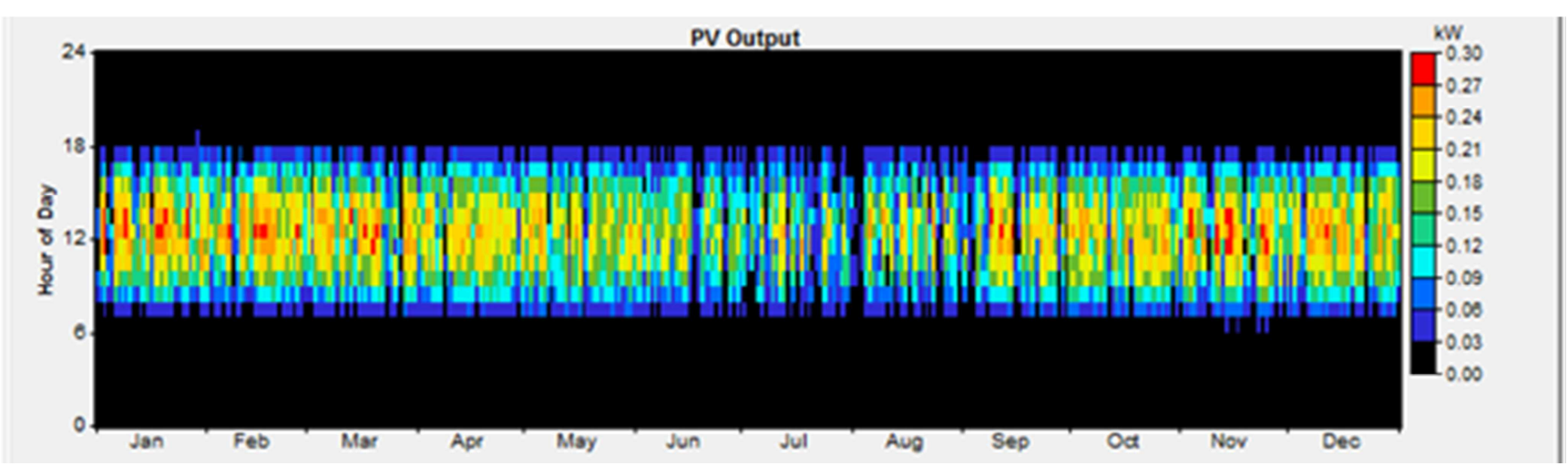

Figure 13. The monthly average PV output.

The amount of monthly average PV output is reduced starting from Jun up to September but there is no need for irrigation water at this period.

\subsection{Monthly Average Water Production}

Now the simulation process operates on the monthly, daily, or hourly basis, visualizing them as "Graphs" and "Tables".

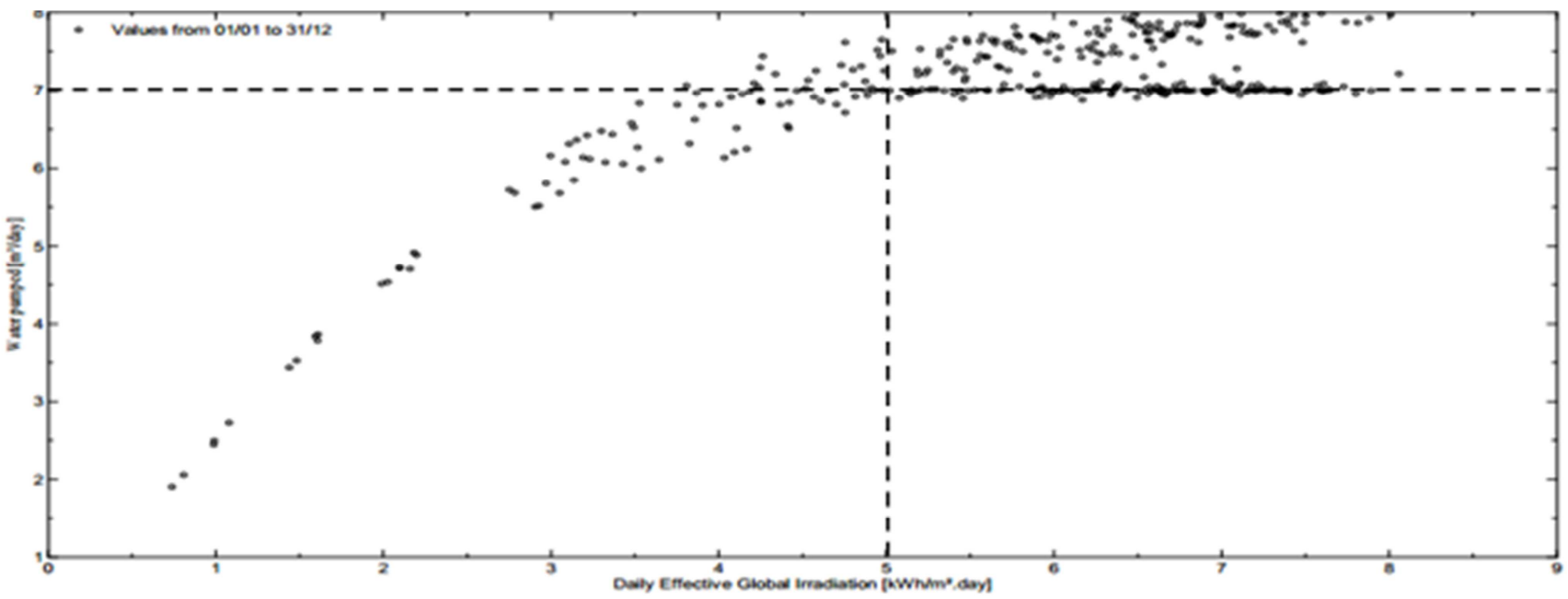

Figure 14. Daily water production versus solar radiation.

At $5.5 \mathrm{kWh} / \mathrm{m}^{2}$ daily solar irradiation the system can be pumped more than $7 \mathrm{~m}^{3}$ of water, which satisfies daily crop water requirement.

\subsection{Annual System Loss Diagram}

Figure 15 represents the overall annual system loss diagram for the system. The amount of annual pumped water is $1512 \mathrm{~m}^{3}$. It is greater than the user's water need. as a result, the designed system satisfies irrigating a hector potato farm.

\subsection{Cost Comparison}

Figure 12 presents the variation of LCCs for PVWP and DWP systems over 20 years (equation 21). Despite the lower operation and maintenance cost and no fuel costs, the high PV modules and the low diesel prices made the PVWP system unaffordable compared to the DWP system in the first year (i. e. PVWPs has higher initial investment cost than DWPs). The PVWPs could still not compete with the DWPs in the fifth year, but gaps became smaller. PVWP has started to be more competitive after the fifth year. Lately, the gap between the two alternatives was further increased. 


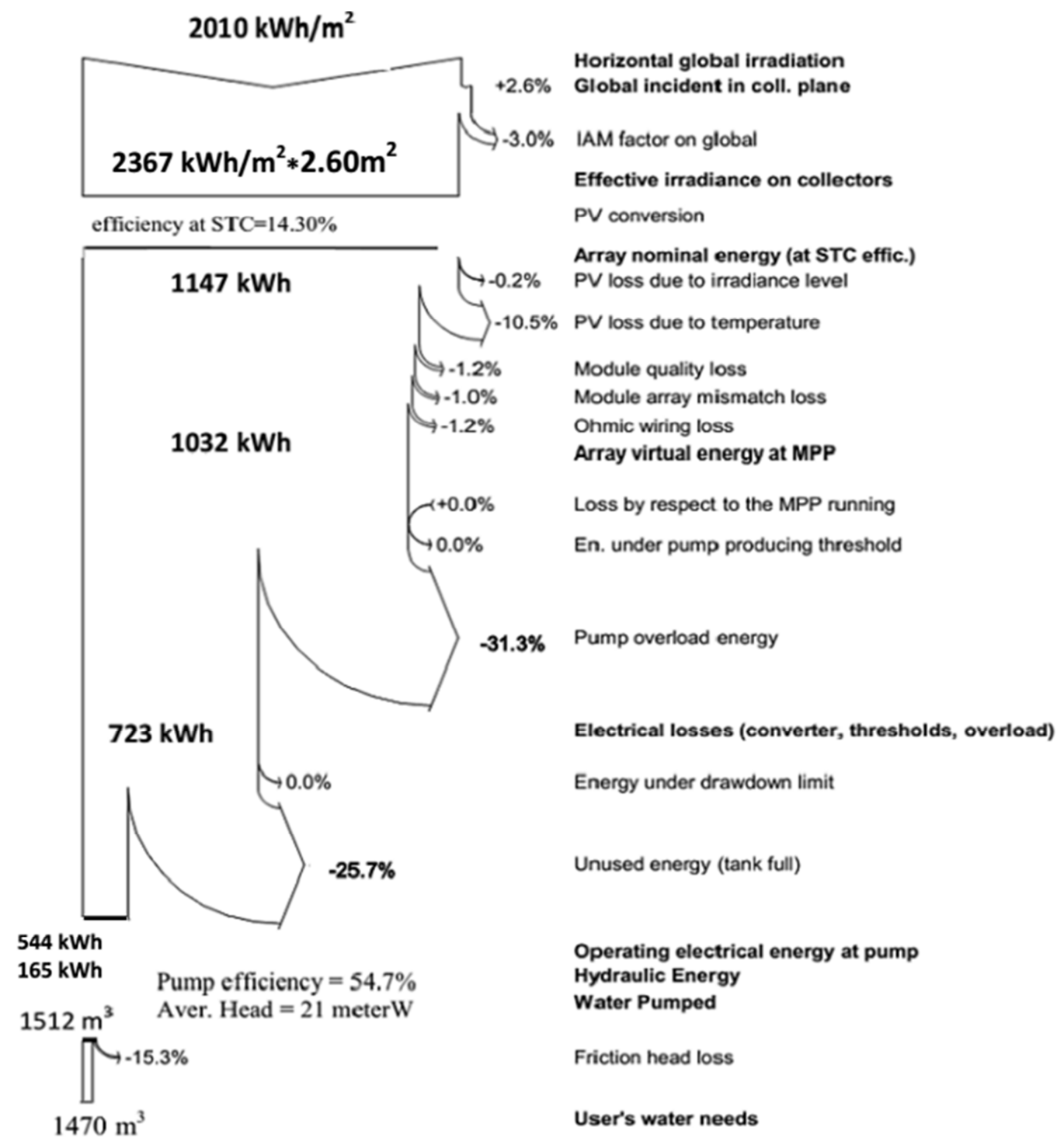

Figure 15. Annual system loss diagram.

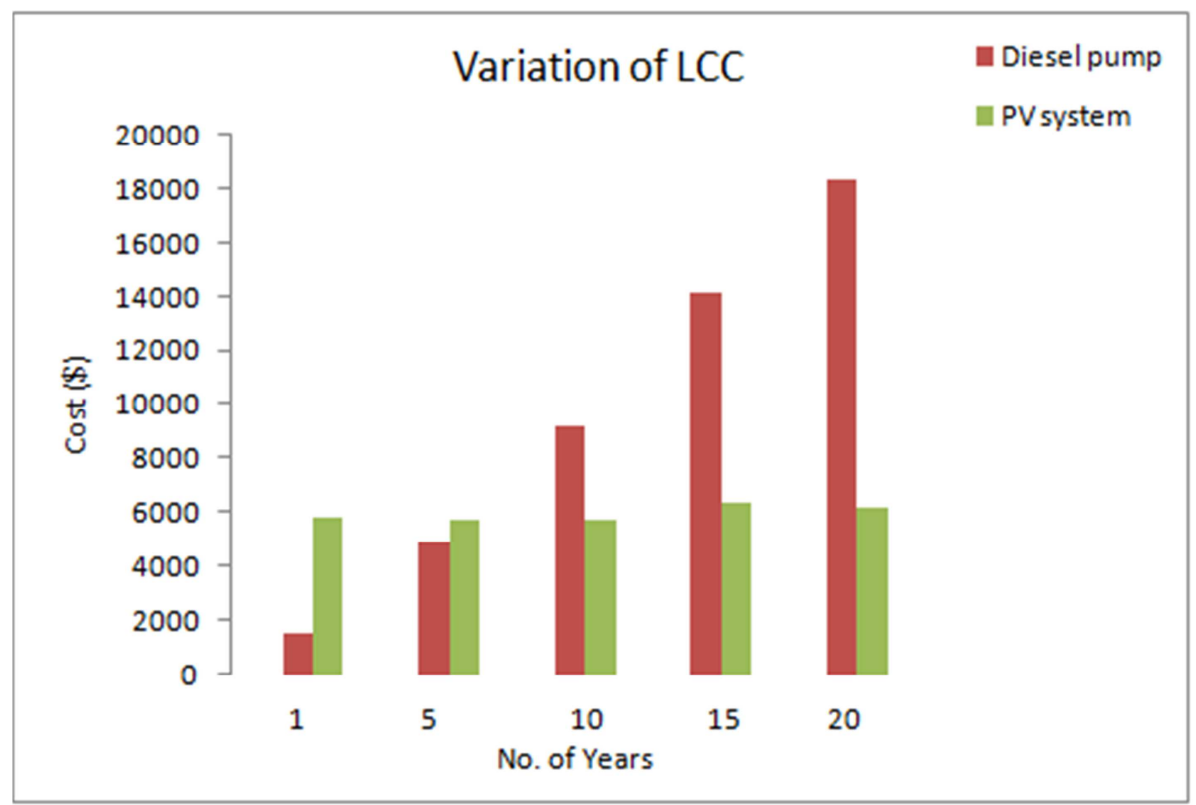

Figure 16. Variation of $L C C$. 


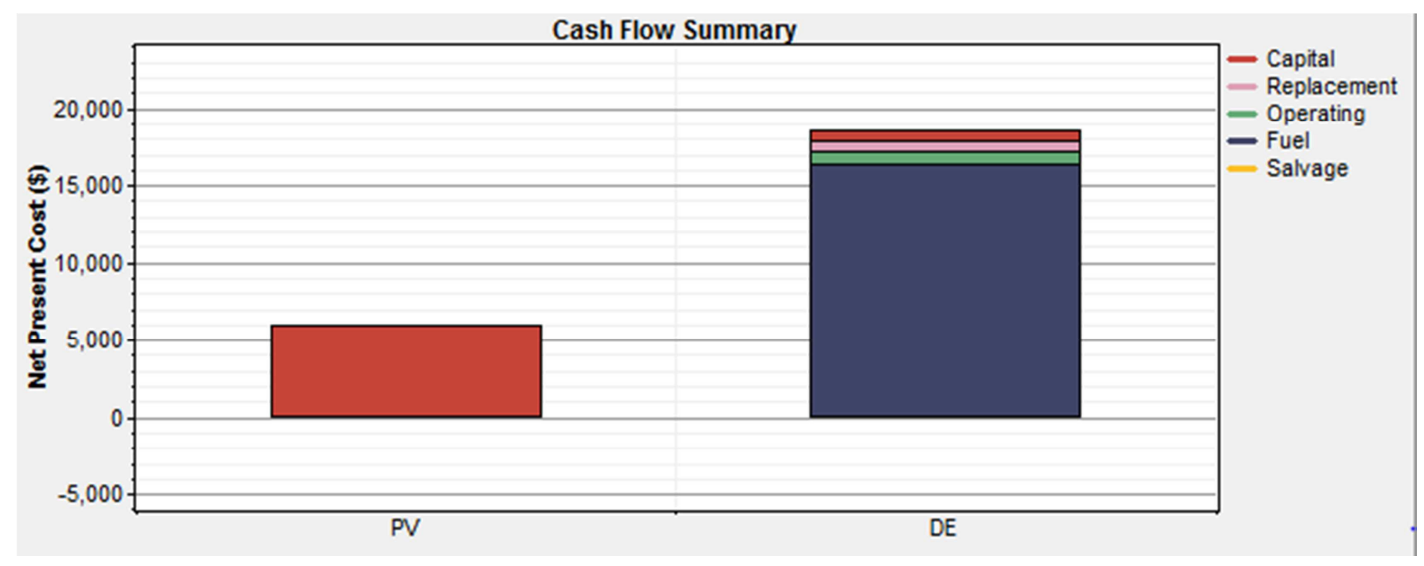

Figure 17. 20-year cost analysis of PVWP and DWP system.

\subsection{Environmental Advantages}

The main cause of global warming is $\mathrm{CO}_{2}$ emission released from different sources of energy. The amount of $\mathrm{CO}_{2}$ emitted varies depends on energy produced and power technology used for conversion. When comparing with diesel powered system; the operation of $\mathrm{PV}$ technology is $\mathrm{CO}_{2}$ emissions free. The calculation of $\mathrm{CO}_{2}$ emissions was done considering of DWPs used to pump water for irrigation purpose. The $\mathrm{CO}_{2}$ emission from DWPs was obtained per year and it is equivalent to $1,500 \mathrm{~kg}$ of $\mathrm{CO}_{2}$ emissions. In addition to $\mathrm{CO}_{2}$, using of diesel water pump has a cause of other pollutants (Table 4).

Table 4. Different pollutants emitted from diesel engine.

\begin{tabular}{lll}
\hline Pollutant & Emissions $\mathbf{~ ( k g / ~} \mathbf{y r})$ & Emissions $(\mathbf{k g} /$ lifetime) \\
\hline Carbon dioxide & 1,500 & 30,000 \\
Carbon monoxide & 9.96 & 199.2 \\
Unburned hydrocarbons & 1.1 & 22 \\
Particulate matter & 0.751 & 15.02 \\
Sulfur dioxide & 8.1 & 162 \\
Nitrogen oxides & 88.9 & 1778 \\
\hline
\end{tabular}

\section{Conclusion}

The study has accomplished its objectives. From the entire discussions good results could be achieved; based on the results of an investigation, the following conclusions were drawn:

1. Assessment of crop water requirements and available solar resources are the two basic design data essential to the design of PVWP system.

2. Solar PV power is more reliable for small scale irrigation for almost all parts of Ethiopia. This is due to the fact that solar energy is in phase with water demand to irrigate crops, secondly; Ethiopia has an abundant supply of solar energy throughout the year. Especially in irrigation periods i. e. from October to May, the horizontal daily solar radiation of the site is about $5.2 \mathrm{Kwh} / \mathrm{m}^{2}$ which is very promising for solar $\mathrm{PV}$ utilization.

3. The designed system of solar PV water pumping system was capable of irrigating a hector area of potato, within 6.5 hrs with a daily water requirement of $7 \mathrm{~m}^{3}$ and total dynamic head of $21 \mathrm{~m}$.

4. The results of the study indicate that irrigating crops using PV systems is beneficial and suitable for long-term investments as compared to diesel-powered engines, as life cycle cost of PV system considering the life span of 20 years was found to be $\$ 6,183.65$ while the life-cycle cost of the diesel engine was ` $\$ 18,365.98$.

5. Based on the projected system lifetime production, the equivalent cost of water for PVWPs and DWPs is $\$ 0.1187 / \mathrm{m}^{3}$ and $\$ 0.3526 / \mathrm{m}^{3}$ respectively.

6. Application of PVWPs instead of DWPs results in an annual reduction of $\mathrm{CO}_{2}$ emission by $1,500 \mathrm{~kg}$.

7. Production of electricity from PVWPs is not only at irrigation seasons. Therefore, further researches are required for using this energy to other purposes especially, at the nonirrigating season.

\section{References}

[1] Shalu Agrawa, Abhishek Jain "Sustainable Development of Solar Irrigation Pumps: Key determinants and strategies" WIREs Energy and Development, 2018.

[2] Prof. Mangesh R. Dhage Prof. Vaibhav S. Girnale Prof. Chetan P. Patil "Review on Solar Photovoltaic Water Pumping System". International Journal for Scientific Research \& Development, 2017.

[3] Muluken Zegeye, Tassew Tadiwos, Abdulkadir Aman "Optimal sizing of solar water pumping system for small-scale irrigation: a Case study of Dangila". International Journal of Renewable and Sustainable Energy, 2014. 
[4] Misrak Girma, Abebayehu Assefa, and Marta Molinas "Feasibility study of a solar photovoltaic water pumping system for rural Ethiopia". AIMS Environmental Science, 2015 .

[5] Asefa Kabade, Abha Rajoriya, U. C. Chaubey "Solar Pump Application in Rural Water Supply - A Case Study from Ethiopia”. International Journal of Energy Engineering, 2013.

[6] Muluken Zegeye, V. Siva Ramakrishnan, M. Premalatha "Optimal Solar Water Pumping System for Small Scale Irrigation: A Case Study on Economical Sizing for Dangila Area of Ethiopia". International Journal of Scientific Engineering and Applied Science, 2017.

[7] Er. P. D. Narale, Dr. N. S. Rathore, Dr. S. Kothari "Study of Solar PV Water Pumping System for Irrigation of Horticulture Crops". International Journal of Engineering Science Invention, 2013.

[8] Aldo Barrueto Guzm án, Rodrigo Barraza Vicencio, Jorge Alfredo Ardila Rey "A Cost-Effective Methodology for Sizing Solar PV Systems for Existing Irrigation Facilities in Chile". MDPI, 2018.

[9] Mya Su Kyi, Lu Maw, Hla Myo Tun "Study of Solar PV Sizing of Water Pumping System for Irrigation of Asparagus". International Journal of Scientific \& Technology Research, 2016.

[10] Kais J. Al-Jumaily, Munya F. Al-Zuhairi, Zahraa S. Mahdi” Estimation of clear sky hourly global solar radiation in Iraq" International Journal of Energy and Environment, 2018.

[11] M. Bala Raghav, K. Naga Bhavya, Y. Suchitra, GUIDE: G. Srinivasa Rao "Design of Solar Power Based Water Pumping System”. IJERT, 2013.

[12] M. Ihsan Ul Haq, Muzammil Kashan, M. Anwar Ul Haq, Muhammad Akmal "Design Analysis of Solar Water Pump for Sustainable Development of Irrigation for Agricultural Sector of Pakis (Muluken Zegeye, 2014) tan”. Research Gate, 2016.

[13] SCB Series, solar pump, Manual for installation, operation and maintenance, Download from www.sunpumps.de.

[14] Design of Small Photovoltaic (PV) Solar-Powered Water Pump Systems, United States Department of Agriculture, Technical Note No. 28, 2010.

[15] Electrical and Mechanical Characteristics of Photo-Voltaic Module, Download From http://www.posharp.com/Businesses/daacacf6-2fa0-4fe2-b6f5 30211a36989a/Panel/BP7180.pdf. 